\title{
Director's salary makes chemists see red
}

Geoff Brumfiel, Washington

The size of the pay package awarded to a former executive director of the American Chemical Society (ACS), which was nearly $\$ 768,000$ in 2002 , has led to protests from members.

According to income-tax papers filed by the society, John Crum received compensation of around $\$ 721,000$ in 2002 , the penultimate year of his 20-year tenure. Crum was also rewarded by roughly $\$ 33,000$ in contributions to benefit plans and a $\$ 14,000$ travel expense account, taking his pay far above the directors of other scientific societies such as the National Academy of Sciences and the American Association for the Advancement of Science ( see chart).

Ten chemists, including Nobel laureate Roald Hoffmann of Cornell University in Ithaca, New York, published a protest letter in the 9 August issue of Chemical and Engineering News, the weekly magazine of the ACS. "It is difficult to believe that ACS could not find a capable executive director for less than three-quarters of a million dollars a year," they wrote.

"To many of our members some of the pay of our executives really looks off the

range for such an organization. Commercial publishers do not disclose salary details, but executive directors are thought to earn in the region of $\$ 500,000$ to $\$ 1.5$ million.

Robert Bergman, a chemist at the University of California, Berkeley, and the lead author of the complaint letter, disagrees with Burke. A consultant being paid to determine the salary of a client might be inclined to choose the highest salary possible, he says. "I feel that this whole arrangement has a built in conflict of interest," he adds.

scale, and I understand that people can feel that way," says James Burke, who chairs the society's board of directors, which approves executive salaries. But he says that pay at the ACS, considered to be the world's largest scientific group, is in line with other organizations of similar size.

"The American Chemical Society is an integrated and complex organization," says Burke. "We have to make sure that we are competitive with private publishers, such as Elsevier and Wiley." He adds that the salaries of ACS executives are analysed every two years by outside consultants and that they are consistently found to be in the appropriate
Daniel Borochoff, president of the American Institute of Philanthropy, a non-profit charity watchdog in Chicago, Illinois, says that the pay may seem unusually high, but it is acceptable if the ACS can prove that the salary is competitive. "The membership may be in an uproar," he says, "but the Internal Revenue Service considers a salary reasonable if it is comparable to what gets paid in either a non-profit or a for-profit job."

Burke expects the issue to be raised at the ACS's annual meeting, held this week in Philadelphia."I would expect that some members will want some more clarification," he says. "And we'll do our best to provide that."

\section{Canada rings the changes for study of northern birds}

\section{Erika Check}

Ornithologists are laying high-tech plans to study the feathered forest dwellers of Canada's northern wilderness.

Billions of birds live in the country's 6 million square kilometres of boreal habitat. The rugged isolation protects around 200 species, but also stymies biologists who want to study them. And the need to understand the area's bird life has become urgent, as oil, gas, timber and mining firms begin to stake claims in the forests.

The Canadian Wildlife Service plans to use innovative techniques, many new to ornithologists, to research the region's birds. "In the past few years, there have been tremendous advances that suddenly make a study of this scale and scope a realistic possibility," says Mike Norton, a boreal biologist with the Canadian Wildlife Service in Edmonton. He discussed the plan at a joint meeting of the American Ornithologists' Union and the Society of Canadian Ornithologists in Quebec City, Canada, on 16-21 August.

The use of one new technique, stable

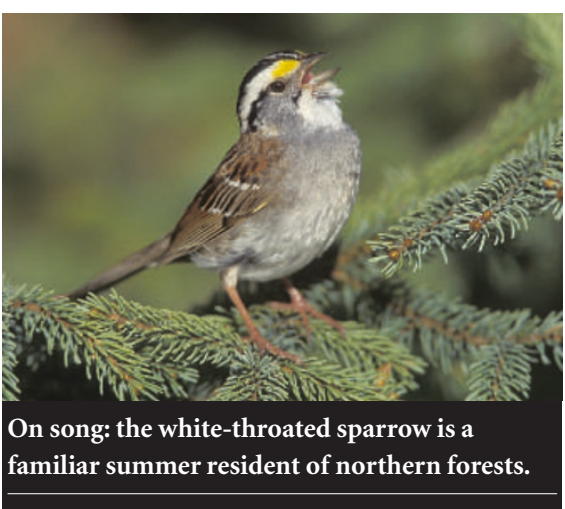

isotope analysis, has been pioneered by Norton's ornithologist colleague Keith Hobson, based in Saskatoon. After trapping a bird, he plucks a single feather and measures the amounts of the different isotopes of hydrogen in the sample. As the levels of individual isotopes differ in water from different parts of the forest, "this lets us define where the birds we capture are coming from, and also where they spend the winter at the end of their migration," says Hobson.

Other new tools include improved omnidirectional microphones to collect faithful sound recordings in the wilderness. Such equipment can help make up for a dearth of trained ornithologists able to go to the boreal forest to identify songbirds, says Norton. And, he adds, better ways of modelling statistical data will help researchers interpret the information they collect.

Norton estimates that the scheme will cost about Can\$15 million (US\$11.5 million) a year and will take a decade to plan fully, although he hopes to start implementing parts of it over the next few years.

Researchers say that the new techniques must be ramped up before much more of the wilderness disappears. They point out that the region is crucial for birds across the entire North American continent. In May 2003, the non-profit group Bird Studies Canada, based in Port Rowan, Ontario, found that one out of every three North American land birds breeds in the boreal region. But the same study also raised a red flag - it reported that 40 boreal species are in decline. 